\title{
O DEFICIT DE LEGITIMIDADE NO PROCESSO POLÍTICO BRASILEIRO. A VIOLAÇÃO DA TEORIA DA DEMOCRACIA
}

EDILENE LôBO

Doutora em Direito Processual Civil pela Pontifícia Universidade Católica de Minas Gerais. Mestre em Direito Administrativo pela Universidade Federal de Minas Gerais. Especialista em Processo Penal pela Universidade de Castilla La Mancha, Espanha. Graduada em Direito pela Universidade de Itaúna. Professora da Graduação e do Mestrado em Direito da Universidade de Itaúna. Advogada.

\section{Resumo}

O presente artigo busca refletir sobre o deficit de legitimidade do processo político brasileiro, na medida em que afasta o povo do controle das eleições e dos mandatos políticos, recusando proteção e concreção do direito fundamental de participação, coluna mestra do Estado Democrático de Direito. Também, quer identificar mecanismos de ativaçáo das consultas públicas como métodos de aferição da vontade popular, que não podem ser substituídas pelo que se lê na crítica impressa. Para alcançar seus objetivos, fez-se ligeira demonstração do funcionamento dos órgãos judiciais eleitorais pátrios, identificando-se as ações do controle das eleições que só podem ser encabeçadas por quatro legitimados (candidato, partido, coligação e Ministério Público), bem como apresentou-se as justificativas do discurso de aplicação para o minimalismo de participaçáo e o excesso de jurisdição (ativismo versus minimalismo).

\section{Palavras-chave}

Legitimidade; Povo; Democracia.

\section{Abstract}

This article seeks to reflect on the legitimacy deficit of the Brazilian political process, in that it withdraws control over the elections and political terms from the people, refusing protection and concretion of the fundamental right of participation, backbone of the democratic state governed by the rule of law. It also seeks to identify activation mechanisms of public pools as measurement methods of the popular will, which cannot be replaced by what is read in the printed review. To achieve its objectives a slight explanation of the Brazilian electoral judicial bodies was made, identifying the control actions of the elections that can only be filed by for legitimates (candidate, political party, party 
coalitions and prosecutors office), and a justification of the application discourse for the minimal participation and excess jurisdiction (activism versus minimalism) was presented as well.

\section{Key words}

Legitimacy; People; Democracy.

\section{Introdução}

O controle sobre o resultado das eleiçóes no Brasil - o julgamento das açóes de impugnações das eleições - é feito por órgãos especializados da Justiça Eleitoral, conforme determina a Constituição brasileira no artigo $118^{1}$, mediante sistema originário da Inglaterra, que o criou por volta de 1868, com o Election Petitions and Corrupt Practices at Elections Act, embora lá, atualmente, a competência seja de órgão da jurisdição ordinária (VIANA, 2008, p. 38).

O modelo brasileiro é também diferente do modelo português, cujo sistema é o de jurisdição constitucional, em que a atuação se dá por provocação da Corte Constitucional, nos termos do art. 223, 2, alínea h, da Constituição daquele País.

É curioso verificar que esses órgãos especializados do judiciário brasileiro detêm competências administrativas, jurisdicionais e legislativas, em verdadeira desordem institucional, mas não são aptos a julgarem demandas ofertadas pelo povo.

Para se ter exemplo ligeiro desse hibridismo, que gera volume descomunal de funçóes, no artigo 22 da Lei no 4737, de 15 de julho de 1965, o Código Eleitoral brasileiro, constam as competências do Tribunal Superior Eleitoral - TSE, que vão desde o processamento e julgamento do registro de partidos e de candidatos à eleição presidencial, passando por decisão dos conflitos entre tribunais regionais e suspeição de seus membros, seguido pelo crimes eleitorais e comuns praticados por seus juízes e membros dos Tribunais Regionais Eleitorais, continuando nas reclamaçóes relativas à contabilidade dos partidos e a apuração da origem de seus recursos, nas impugnaçóes à apuração da eleição presidencial, nos pedidos de desaforamento de feitos, desaguando nas reclamaçóes contra seus próprios juízes, açóes rescisórias de seus julgados e recursos contra as decisóes dos tribunais regionais (LÔBO, 2010, p. 64).

O TSE também tem a atribuição de elaborar seu regimento interno, organizar suas secretarias, gerir pessoal, propor criação dos tribunais regionais, fixar as datas das eleições

1 Art. 118. São órgãos da Justiça Eleitoral: I - o Tribunal Superior Eleitoral; II - os Tribunais Regionais Eleitorais; III - os Juízes Eleitorais; IV - as Juntas Eleitorais. 
presidenciais, de senadores e de deputados federais (embora matéria já disciplinada em lei ${ }^{2}$ ), aprovar divisão do Estado em zonas eleitorais, expedir instruções normativas, fixar diárias, organizar o envio da lista tríplice ao Presidente da República para a escolha e a nomeação de seus membros, responder a consultas eleitorais feitas por autoridades e partidos, autorizar a contagem de votos, requisitar força federal para acompanhar os pleitos, organizar e divulgar súmulas, requisitar funcionários e publicar de boletim eleitoral, tudo conforme o artigo 23 do Código Eleitoral (LÔBO, 2010, p. 65).

Não bastasse, configurando a esse órgão de cúpula judicial a feição de legislador, está a competência para responder consultas. Essa competência elastece a jurisdição para além do devido processo legal, permitindo a interpretação de teses desligadas de casos concretos, o que acaba por impor força sancionatória a pareceres. Associada à anterior, outra competência preocupante é a que prevê a expedição de instruçóes normativas e a adoção de quaisquer providências para a execução da legislação eleitoral. Com tal grau de indefiniçáo sobre o significado da expressão "quaisquer providências", a permissão para tais práticas tem gerado excesso violador do ordenamento que se quer regular, com a figura anômala do Tribunal que legisla (LÔBO, 2010, p. 66).

Há, também, focando o interesse estadual, os tribunais regionais sediados nas capitais dos estados federados, com competências similares às do Tribunal Superior Eleitoral, adicionadas àquelas de "designação das juntas eleitorais, a indicação, ao TSE, das zonas eleitorais ou seçóes em que a contagem deve ser feita pela mesa receptora, a apuração das eleiçóes de governador/vice e membros do Congresso Nacional, a divisão da circunscrição em zonas eleitorais, a organização do fichário de eleitores, a expedição de mapas e boletins de apuração". (LÔBO, 2010, p. 66).

Sobre os juízes eleitorais, base dessa justiça especializada, a despeito de o Código Eleitoral lhes atribuir competências tão grandes quanto aos tribunais regionais, eles não ocupam cargos da carreira própria, eis que são tomados de empréstimo de outros órgãos judiciais ${ }^{3}$. O mesmo que se dá com os juízes regionais e os ministros do TSE - merecendo registro que nesses tribunais, juntamente com os juízes tomados de empréstimo de outros tribunais, há dois membros em cada, nomeados pelo Presidente da República, escolhidos dentre seis cidadáos de notável saber jurídico.

Além desses órgãos eleitorais, tem-se, na cúpula, o Supremo Tribunal Federal brasileiro, que, além de Corte Constitucional, detém competência para julgar, mediante recurso extraordinário, as causas decididas em única ou última instância eleitoral, quando a decisão recorrida contrariar dispositivo da Constituição da República (art. 102, III, “ $a$ ”).

2 No artigo $1^{\circ}$ da Lei no 9.504, de 30 de setembro de 1997, as eleiçóes “dar-se-ão, em todo o País, no primeiro domingo de outubro do ano respectivo".

3 Como se tem dos artigos 32, 25, inciso I, II e III e 16, inciso I, todos do Código Eleitoral. 
A despeito dessa profusão de normas infraconstitucionais, oriundas do regime ditatorial anterior e postas no atrasado Código Eleitoral de 1965, não há na atual Constituição brasileira qualquer previsão sobre atribuiçóes do judiciário eleitoral.

Esse registro não passa despercebido para Marcelo Roseno de Oliveira:

Vê-se, portanto, que as regras hoje vigentes acerca da competência da Justiça Eleitoral foram fixadas sob a égide da ordem constitucional decaída, e embora haja o TSE proclamado a ausência de incompatibilidade substancial entre elas e a Constituição Federal, verifica-se inegável conflito entre algumas das disposiçôes do Código Eleitoral e a Lei Maior. (OLIVEIRA, 2010, p. 94).

Resta evidente, portanto, que o sistema judicial eleitoral brasileiro revela um acumulado de funçóes que só reforça a hipertrofia da atividade judicial de controle das eleiçóes, embora não previstas expressamente no texto constitucional. Por outro lado, em contradição surpreendente, o povo ${ }^{4}$ é excluído da ativação desse controle porque a legislação brasileira não o arrola dentre os legitimados ao processo eleitoral, eis que só admite o manejo das ações típicas por partidos, coligaçóes (espécie de coalizão formada com a aglutinação de vários partidos e com durabilidade limitada às eleiçóes ${ }^{5}$ ), o Ministério Público ou candidatos.

Nesse aspecto, da (não) inclusão do povo no controle das eleiçôes, vê-se diferença significativa com o modelo português, que a admite, ao menos por interpretação lógica do artigo 52º, item 1, da Constituição da República Portuguesa: “Todos os cidadãos têm o direito de apresentar, individual ou colectivamente, aos órgãos de soberania, aos órgãos de governo próprio das regióes autónomas ou a quaisquer autoridades petiçóes, representaçóes, reclamaçóes ou queixas para defesa dos seus direitos, da Constituição, das leis ou do interesse geral [...]."

4 Canotilho, ao conceber o povo como titular do poder constituinte, destaca a dificuldade de conceituaçấo e grandeza de sentidos que tangenciam a mencionada expressão. Com apoio em Friedrich Müller, afirma que povo "[...] não é um conceito unívoco, mas plurivoco". Na sequência, remete-se a Peter Häberle para assimilar povo como uma "grandeza pluralistica", composta por inúmeros fatores de força cultural, social e política. Lado outro, adverte que nas democracias atuais o conceito de povo náo corresponde a "bloco de cidadão activos", "cidadãos proprietários", tampouco "classe do proletariado", conforme pretendiam os jacobinos, os liberais ou os revolucionários destinados à configuraçáo de sociedade classista, respectivamente. Assim, declara que "O povo concebe-se como povo em sentido político, isto é, grupos de pessoas que agem segundo ideias, interesses e representação de natureza política. Afasta-se, assim, um conceito naturalista, étnico ou rácico de povo caracterizado por origem, língua elou cultura comum". (CANOTILHO, 2003. p. 75).

5 Art. $6^{\circ}$ É facultado aos partidos políticos, dentro da mesma circunscrição, celebrar coligaçôes para eleição majoritária, proporcional, ou para ambas, podendo, neste último caso, formar-se mais de uma coligação para a eleição proporcional dentre os partidos que integram a coligação para o pleito majoritário (BRASIL. Lei no 9.504, 1997). 
Comentando esse dispositivo constitucional português, J.J. Canotilho e Vital Moreira explicam seu sentido naquele País:

[...] A Constituição configura o direito de petição, lato sensu (no 1) como direito político, como instrumento de participação dos cidadãos na vida política (v. nota I ao art. 48\%). Admite que a petição se dirija quer à defesa de direitos pessoais (reclamaçôes e queixas), quer à defesa da Constituição, das leis ou do interesse geral (petiçôes stricto sensu e representaçôes). A caracterização do direito de petição como um direito de participação política, e não como um direito pessoal, justifica que ele possa ser exercido independentemente da existência de qualquer gravame pessoal ou lesão de interesses próprios, ou seja, em defesa de legalidade constitucional ou do interesse geral (cf. L no 83/95, direito de participação procedimental e da acção popular). No entanto, além de um direito de participação política em si mesmo, o direito de petição é também tal como o direito de acção judicial (art. 20\%), uma garantia em sentido próprio, de natureza extrajudicial, para defesa de todos os direitos e interesses legalmente protegidos, a começar pelos demais direitos, liberdades e garantias. (CANOTILHO e MOREIRA, 2007, p. 693).

Aliás, o direito de petição se estende a todos os países membros da União Européia, como se tem do artigo $44^{\circ}$ da Carta dos Direitos Fundamentais da União Européia, conforme esclarece Maria Luisa Duarte, ao comentá-lo (DUARTE, 2013, p. 514).

Vale dizer que a Constituição brasileira também prevê o direito de petição como fundamental, assentando-o no artigo $5^{\circ}$, inciso XXXIV, mas o Tribunal Superior Eleitoral o interpreta diferente, negando-lhe validade diuturnamente, como se tem no julgamento do Agravo Regimental na Representação no 1251, relatado pelo Ministro Francisco Cesar Asfor Rocha, precedente representativo da consolidação do tema na jurisprudência eleitoral:

Possuem legitimidade para o ajuizamento de representação visando a abertura de investigação judicial eleitoral apenas os entes arrolados no art. 22 da Lei Complementar no 64/90, entre os quais não figura o mero eleitor, conforme a reiterada jurisprudência do TSE.

O direito de petição consagrado no art. 5 XXXIV, a, da Constituição, embora sendo matriz do direito de ação, com o qual não se confunde, encontrando este última regulação específica na legislação infraconstitucional, daí decorrendo não poder ser exercido de forma incondicionada. (BRASIL. Tribunal Superior Eleitoral, 2006)

Curioso é que desde a promulgação da Constituição de 1988, com a redação do parágrafo único do artigo primeiro, se tem claro o referente lógico para o desempenho das funções estatais: os órgãos e agentes detém atribuições e funções, não mais poder, eis 
que este é de titularidade do povo, que o desempenha de forma satisfatória no modelo participativo de Estado, podendo delega-lo, elegendo representantes. A legitimidade da atuação estatal, por quaisquer de seus órgãos, portanto, só se dá com a participação efetiva dos populares.

Da mesma forma, e ainda mais premente, no exercício da função judicial, órgãos e agentes a deveriam realizar por meio do processo, garantia constitucional de ampla argumentação, que é ativada pelo direito humano fundamental de acesso à jurisdição - direito de ação - instituída no inciso XXXV do art. $5^{\circ}$ da Constituição brasileira.

O processo, não mais instrumento de agentes estatais, se estrutura nos princípios da ampla defesa, do contraditório e do devido processo legal, este último entendido como estrutura lógico-procedimental preexistente na norma de regência, que se completa com a livre atuação dos interessados, sem redução de seu poder de participação (GONÇALVES, 1992).

Com isso, observa-se que, no paradigma da democracia participativa, diferente da ordem constitucional brasileira pretérita, o que confere legitimidade ao desempenho da função judicial é a ampla participação daquele do povo por meio do devido processo legal, no qual se assegure desenvolvimento dialogal do discurso de construção, desconstrução ou revisitação do direito.

$\mathrm{Na}$ mesma linha, o desempenho do munus político de representação dos grupos sociais para formação da vontade da maioria, por meio das normas e atos produzidos, só é legítimo se houver atuação dos interessados desde os primórdios do processo político de escolha, assando pelo controle desse mesmo processo, culminando na interaçáo entre representantes e representados para busca da pauta comum de interesses, finalizando no controle das açóes políticas dos mandatários, para cotejá-las com o precitado rol de interesses.

\section{A Mitigação da Participação e a Violação da Teoria da Democracia}

Conclui-se, até por intuição, que o grau de participação do povo nos processos judicial e político dá o tom de legitimidade do sistema e revela a aplicabilidade da teoria da democracia e do respeito aos direitos humanos, náo havendo justificativa para a exclusão verificada no excerto revelador da jurisprudência do Tribunal Superior Eleitoral, explorado neste trabalho.

A correlação entre norma e aplicação prática, entretanto, não privilegia tais mandamentos no Brasil, justificando o tema debatido, que provoca o pensar sobre jurisdição e poder, democracia e legitimidade, povo e representação.

A aplicação da teoria procedimental constitucionalizada, asseguradora da ampla discursividade entre os interessados, particularmente no controle judicial das eleiçôes, vem 
sendo mitigada há bastante tempo, mesmo com críticas veementes (LÔBO, 2010, p. 120). Ao afastar o sujeito popular da esfera de controle do resultado das eleiçóes, os tribunais eleitorais e os legisladores impóem importante deficit de legitimidade na constituição dos mandatos eletivos, menoscabando um dos direitos humanos mais importantes.

Dessa forma, o modelo de processo judicial ou político na esfera eleitoral não se enquadra no paradigma de Estado Democrático de Direito, desrespeitando a soberania popular por vários ângulos de exame, agredindo em cheio os direitos fundamentais do povo de participação na vida política nacional em todas as latitudes, assim como de controlar os mandatos por ele conferidos aos representantes (LÔBO, 2010, p. 128). É, nesse diapasão, clara e insofismável a violação da teoria constitucional da democracia.

É bem verdade que encontra-se explicação política para a escolha feita pelo legislador infraconstitucional pátrio, que mira o passado, no modelo de Estado Social, mas, o reforço desse entendimento pelos Tribunais Eleitorais, e em especial pelo Supremo Tribunal Federal brasileiro, revela o desprestígio do paradigma da democracia participativa exatamente pelos órgãos técnicos que têm por missão protegê-lo.

Por outro lado, essa posição ideológica das Cortes de Justiça brasileiras traz à lume concepçáo paternalista e de tutela do povo, extraída do paradigma de Estado Social, como se o povo não fosse capaz de efetuar escolhas políticas e jurídicas, enfim, de se conduzir de forma livre e autônoma.

Basta ver a explicação doutrinária para tal excesso, com base em "virtudes cívicas", pretendidas a todo custo pelo regime de horror vivido no Brasil em meados da década de 1960 até meados dos anos 1980:

Na sociedade brasileira, um caso de capitalismo retardatário e de democracia política incipiente, a presença expansiva do direito e de suas instituiçóes, mais do que indicativa de um ambiente social marcado pela desregulação e pela anomia, é a expressão do avanço da agenda igualitária, em um contexto que, tradicionalmente, não conheceu as instituiçóes da liberdade. Neste sentido, o direito não é “substitutivo" da República, dos partidos e do associativismo - ele apenas ocupa um vazio, pondo-se no lugar deles, e não necessariamente como solução permanente. Décadas de autoritarismo desorganizaram a vida social, desestimularam a participação, valorizando o individualismo selvagem, refratário à cidadania e à idéia de bem comum. A intervenção normativa e a constituição de uma esfera pública vinculada diretamente ou indiretamente ao Judiciário, como no caso das açôes públicas e dos Juizados Especiais, em vez de manterem os indivíduos à parte da república, pode se constituir, dependendo dos operadores sociais, em uma pedagogia para o exercício das virtudes cívicas. (VIANNA; CARVALHO; MELO; BURGOS, 1999, p. 150). 
Essa ausência de maioridade conduz, inevitavelmente, ao alheamento e à alienação, fechando ciclo vicioso: o povo não tem autonomia porque é tutelado e é tutelado porque não tem autonomia.

Piora o quadro, que passa a ser pintado com cores sombrias, quando se observa invasão sistemática e acelerada desse espaço de debate popular por órgãos estatais, em particular pelo Judiciário nacional, representado por alguns agentes dos tribunais de cúpula, que ganham ares de super-heróis, verdadeiros protagonistas de romances de capa e espada ${ }^{6}$.

Localiza-se, nesse ponto, o fenômeno do ativismo judicial em sede de direitos políticos, ideologia que, desnudada, apresenta retrocesso e salto para trás na democracia participativa e no Estado Constitucional de direitos, gerando importante decréscimo de legitimidade no controle de mandatos, reduzindo o espaço de atuação do povo na esfera pública.

Outro aspecto a se observar, quanto a esse fenômeno, que acaba por avantajar a função do agente estatal e minimizar o discurso, é defendido em nome da opiniâo e do clamor públicos ${ }^{7}$, sem que se demonstre por quais métodos científicos de aferição da vontade popular se chegou a tal conclusão. Embora se diga às mancheias sobre "voz das ruas", não se cuida de ouvi-la por meio dos mecanismos constitucionais da democracia participativa, como as consultas públicas.

$\mathrm{O}$ argumento simplista, subserviente aos grupos econômicos de mídia e de costas para o povo, consiste na aferição da reação social por meio das "fortes cores pela crítica

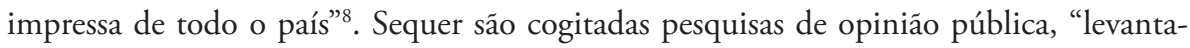
mento estatístico realizado com base em uma amostra proveniente da população que está sendo investigada” (OLIVEIRA; ROMÃO; GADELHA, 2012, p. 24).

Nem se diga da oitiva direta do povo exercitando direitos políticos constitucionais ofertados, a se ver que, ao longo de sua história recente, o Brasil realizou apenas três grandes consultas populares nacionais: referendo pelo sistema de governo em 1963, plebiscito pela forma de Estado e de governo em 1993 e referendo sobre desarmamento em $2005^{9}$.

6 O Ministro Luiz Fux, do Supremo Tribunal Brasileiro, julgando a Ação Declaratória de Constitucional $n^{\circ} 29$, manejada para questionar a validade da Lei Eleitoral no 135/2010, apelidada de Ficha Limpa, acórdão publicado no Diário do Judiciário eletrônico de 29.06.2012, reconheceu que "São notórios a crise do sistema representativo brasileiro e o anseio da população pela moralização do exercício dos mandatos eletivos no país". Disse que a prova disso é "o fenômeno da judicialização da política" concluindo que o ativismos judicial é produto da crise, logo, parte do problema. Mas, a seu ver, revelaria "reconhecimento da independência do Poder Judiciário no Brasil"!

7 O mesmo Ministro, no mesmo acórdão referida na nota anterior, registrou que o papel do Supremo Tribunal Federal, e do Judiciário, é o de “instância contramajoritária de proteção dos direitos fundamentais e do regime democrático. No entanto, a própria legitimidade democrática da Constituição e da jurisdição constitucional depende, em alguma medida, de sua responsividade à opiniáo popular”.

8 Idem, ibidem.

9 Conforme consultado no seguinte endereço :<http://www.tse.jus.br/eleicoes/plebiscitos-e-referendos/ plebiscito-e-referendo>. Acesso em 31 mar. de 2015. 
Néviton Guedes explica que mecanismos da democracia direta ou semi-direta quase que desapareceram nos Estados contemporâneos, por causa da "acentuada complexidade nas expectativas e valores sociais, a multiplicidade e especificidades dos problemas a resolver, os riscos aí envolvidos, assim como a exigência de crescentes e específicos conhecimentos técnicos para sua solução" (GUEDES, 2013, p. 674).

Para esse autor, apanhando ensinamentos de Canotilho, também teria contribuído para tal realidade, "o medo de que a vontade popular pudesse ser manipulada, seja por líderes carismáticos, na forma de alguma espécie de Cesarismo ou Bonapartismo (veja-se o exemplo de Hitler e do Partido Nacional-Socialista - NSDAP), seja pela possibilidade de os meios de comunicação atuarem, nas sociedades de massa, como agenda-setter, isto é, agendarem os temas que acabam ganhando a atenção e a preferência popular" (GUEDES, 2013, p. 674).

Ocorre que, mesmo sem uso de tais instrumentos, os meios de comunicação no Brasil já pautam os temas de seu interesse, indicando ao povo sobre o que pensar e agir, insuflando manifestaçóes públicas apoiadas em verdades reveladas. Isso significa que a realidade brasileira, de desuso das consultas públicas, como já se disse, não corrobora a explicação dada, embora também sofra a manipulação anotada.

De todo modo, no Brasil, a regulação do assunto está na Lei no 9.709, de 18 de novembro de 1998 , cujo art. $2^{\circ}$ preconiza que "Plebiscito e referendo são consultas formuladas ao povo para que se delibere sobre matéria de acentuada relevância, de natureza constitucional, legislativa ou administrativa”.

Nos parágrafos $1^{\circ}$ e $2^{\circ}$ desse mesmo artigo tem-se a conceituação de ambos os tipos: "O Plebiscito é convocado com anterioridade a ato legislativo ou administrativo, cabendo ao povo, pelo voto, aprovar ou denegar o que lhe tenha sido submetido" e "O referendo é convocado com posteridade a ato legislativo ou administrativo, cumprindo ao povo a respectiva ratificação ou rejeição".

A competência para convocar tais consultas é do Parlamento Federal, por um terço dos membros de quaisquer das Casas, Câmara dos Deputados ou Senado, e se fará mediante decreto legislativo (artigo $3^{\circ}$ ). Se aprovada a convocação, caberá ao Presidente do Congresso nacional dar ciência à Justiça Eleitoral, que deverá: a) fixar a data da consulta; b) tornar pública a cédula respectiva ou a disposição na urna eletrônica; c) expedir instruçóes para a realização da consulta; d) assegurar propaganda gratuita no rádio e na televisão aos partidos políticos e às frentes suprapartidárias organizadas em torno da matéria sob consulta, para que divulguem e defendam suas opinióes (artigo $8^{\circ}$, incisos I a IV).

Mais uma vez, se vê a importância da Justiça eleitoral brasileira nesse processo porque, nos termos do artigo 10 da lei em comento, o plebiscito ou referendo será considerado aprovado ou rejeitado por maioria simples, "de acordo com o resultado homologado pelo Tribunal Superior Eleitoral". 
A propósito, com a utilização da tecnologia na coleta do voto pela urna eletrônica, a extensão territorial, assim como a complexidade de se convocar grandes contingentes populacionais, não são mais problemas administrativos que justifiquem o desuso das consultas populares.

\section{O Diálogo Aberto Garantidor dos Direitos Políticos}

Tal como disse Jónatas Machado (2013), Professor da Faculdade de Direito da Universidade de Coimbra, se referindo à liberdade de manifestação, "A esfera de discurso público e inerente a uma ordem constitucional republicana, livre e democrática baseia-se no reconhecimento da centralidade da discussão pública de todas questóes de interesse público, de forma robusta, aberta e desinibida, a partir de diferentes pontos de vista e com base na livre troca de ideias e opinióes, sem qualquer tipo ou forma de censura”.

Essa proposta de diálogo aberto acaba por impactar de modo indelével a vida do povo, versando críticas que permitam afirmação, reconstrução ou demolição de modelos, servindo bem à teoria da democracia participativa que exige proteção à soberania popular em todas as esferas de atuação estatal, particularmente na política e na judicial.

Como bem anotou o Professor Jónatas Machado (2013), permitindo com suas palavras justificar ainda mais claramente a pertinência do tema em foco, "a tutela da dignidade humana e do livre desenvolvimento da personalidade constituem elementos estruturantes do Estado Constitucional [...] traves mestras de uma sociedade livre, pluralista e democrática, assentes num princípio de dignidade e autonomia”.

Atende à ideia de pluralismo e legitimidade permitir o controle dos pleitos pelo povo por meio do princípio do discurso no contexto do Estado Democrático de Direito, maximizando a efetividade dos direitos constitucionais de participação, assim como buscando sua vontade diretamente, sem subterfúgios linguísticos, utilizando as consultas públicas como as verdadeiras pesquisas de opiniáo, que resultarão reverberar a autêntica "voz das ruas".

Ao contrário, se afastando da legitimidade que deveria perseguir, não há legitimidade na decisão judicial ou política que se alheia ao paradigma constitucional adotado. Menos ainda quando se pretende identificar a vontade do povo, o clamor público, nas fortes cores da crítica impressa de todo o país, muito embora não lance mão das consultas públicas como legítimo método de controle e legitimação da ação estatal.

A literatura especializada eleitoral é repetitiva em asseverar que a legitimidade para controle judicial dos pleitos advém de lege lata e não do paradigma constitucional, utilizando vagos critérios de utilidade para explicar a recusa da participação do povo no exercício desse importante direito fundamental (LÔBO, 2010, p. 117). 
Isso, ao lado da ideologia dominante nos órgãos judiciais brasileiros, justificando o ativismo redutor da participação popular pelo processo, bem como a rejeição a teorias aplicáveis ao processo judicial eleitoral, retira deste a principiologia estruturante de audição bilateral, dialética, viabilizadora da paridade de armas, enfim, torna-o incapaz de possibilitar igualdade perante a jurisdição.

Peter Haberle, afirmando a teoria da democracia como legitimação do poder, inclusive judicial, acentua:

[...] a democracia não se desenvolve apenas no contexto de delegação de responsabilidade formal do Povo para os órgãos estatais (legitimação mediante eleiçôes), até o último intérprete formalmente competente, a Corte Constitucional. Numa Sociedade aberta, ela se desenvolve também por meio de formas refinadas de mediação do processo político e pluralista da política e da práxis cotidianas, especialmente mediante a realização dos Direitos Fundamentais (Grundrechtsverwirklichung), tema muitas vezes referido sob a epígrafe do "aspecto democrático" dos Direitos Fundamentais. [...]

Povo não é apenas um referencial quantitativo que se manifesta no dia eleição e que, enquanto tal, confere legitimidade democrática ao processo de decisão. Povo é também um elemento pluralista para a interpretação que se faz presente de forma legitimadora no processo constitucional: como partido político, como opinião científica, como grupo de interesse, como cidadão. (HABERLE, 2002, p. 36-37)

A par desse raciocínio, a autonomia da vontade popular deve superar a concepção vigente no Brasil, de privilégio ao sistema de representação política e menoscabo dos titulares do poder que a confere.

O protagonismo político conferido aos representantes pátrios - sejam os eleitos, do Parlamento e do Executivo, sejam os nomeados, do Judiciário - como se tem nas páginas dos principais jornais e revistas do Brasil nos últimos tempos, longe de demonstrar a efetiva participaçáo popular, aponta o distanciamento e a ignorância das reais pretensóes de tais agentes, aumentando a desconfiança nos seus propósitos ${ }^{10}$.

10 Como na natureza, o poder abomina o vácuo. Na política, quando alguém fica fraco, outro se fortalece. É o que ocorre agora em Brasília. Dilma Roussef ainda não completou três meses de governo e os sinais de fadiga de material emanados do Palácio do Planalto são tấo evidentes que se poderia dizer que ela está em fim de segundo mandato. Dilma não pode aparecer em público sem que desperte um coro de vaias. Suas entrevistas coletivas ou pronunciamentos à nação pela televisão são a senha para que as pessoas abafem suas palavras com panelaços. [...] O caso de Dilma está ajudando a elevar no horizonte político a figura de Eduardo Cunha, o deputado federal pelo PMDB do Rio de Janeiro que, contra a vontade do Executivo, foi posto pelos seus pares na presidência da Câmara. Cunha é o personagem de uma reportagem especial desta edição de VEJA dedicada a explicar o novo arranjo de forças em Brasília depois das manifestaçôes populares do domingo 15 de março. O governo ficou perplexo e sem ação com 
Norberto Bobbio, na década de 80 , se referindo à Itália, quando ainda não se pensava na virada político democrática no Brasil, afirmava em discurso bastante atual que a democracia, "governo do poder visível", deve ter seus atos desenvolvidos em público, "sob o controle da opinião pública” (BOBBIO, 1999, p. 208).

Para se contrapor às autocracias, em que a atuação dos agentes estatais é segredada, o chamado "criptogoverno". Ao contrário do "criptogoverno", de opacidade endógena, a democracia é translúcida para que todos os atos dos representantes sejam convalidados ou desfeitos pelos seus destinatários - sujeitos populares -, os únicos a deterem soberania capaz de conferir legitimidade ao sistema político e judicial.

\section{Conclusões}

Resta bem explicitada a interdependência entre direitos políticos e democracia, ou seja, "um regime de organização do poder político em que prevalece o domínio do povo" (GUEDES, 2013, p. 658).

Nos regimes democráticos contemporâneos, o povo, protagonista da democracia, é o destinatário do desempenho das funçóes estatais de legislar, administrar e julgar, as mesmas que só detém legitimidade se contarem com a sua participação.

Essa simbiose entre poder, participação e democracia, apresenta a pedra fundamental do sistema político brasileiro, que conta com as consultas públicas para aferição do "clamor popular".

Entretanto, a recusa sistemática em lançar mão de tais consultas e de permitir a participação do povo nas açóes eleitorais viola a teoria da democracia, jogando por terra o pilar da organização social, violando direitos humanos essenciais.

Noutro aspecto, apresenta discurso de aplicação de paradigma havido sob ordem jurídica pretérita, violando o atual referente constitucional, exigindo reparação na

a inesperada magnitude dos protestos, em especial em São Paulo, onde mais de 1 milháo de pessoas formaram um mar verde-amarelo na Avenida Paulista. O grito das ruas não pode ser desmembrado das crises na economia e na política com as quais a presidente já estava tendo que lidar. Em horas como essa, os chefes do Executivo buscam apoio em seus aliados no Congresso. Em horas como essa, o que tem ocorrido no Brasil desde a redemocratização, há trinta anos, é o presidente da Câmara servir como uma das tábuas de salvação do presidente. Não é o caso agora. Cunha decidiu encarnar a independência dos poderes interpretando ao pé da letra a Constituição. [...] Por qualquer ângulo que se examine o quadro político, o que se nota é uma presidente acuada pela impopularidade, pela falta de apoio de seu próprio partido, o PT, e pela súbita tomada de posição do Parlamento, algo que fazia muito náo se via no Brasil. Este momento único pode degenerar em uma briga de personalidades - Dilma versus Cunha -, o que seria ruinoso. Mas pode também ser o momento de reequilíbrio da correlação de forças na democracia brasileira, há tempos marcada por um Executivo degraus acima do Legislativo e do Judiciário (REVISTA VEJA, Săo Paulo: Abril, ed. 2418, ano 48, n. 12, p. 12, 25 mar. 2015). 
intepretação da legitimação para agir nas açôes eleitorais, bem como, marcando a omissão constitucional dos órgãos públicos ao não adotarem o referendo e o plebiscito como modernos mecanismos constitucionais de aferição da vontade popular para grandes temas de interesse nacional.

Atualmente, em tempos de mais uma reforma política brasileira, ao invés de servir como fator de tensão entre Executivo, Legislativo e Judiciário, os grandes temas que a permeiam deveriam ser lançados para a decisão do povo por meio de consultas públicas.

Destacam-se, a seguir, várias indagaçóes a serem direcionadas aos sujeitos populares para sua resposta, ao invés de serem mantidas sob o controle do Presidente da Câmara dos Deputados, que, como se lê na mídia impressa, trava verdadeira batalha com o Executivo, certamente mirando as próximas eleiçóes presidenciais, cuidando, antes de tudo, de seus próprios interesses pessoais e políticos ${ }^{11}$.

Eis algumas questóes:

- financiamento público ou privado de campanhas eleitorais?

- fim da reeleição no Executivo e no Legislativo?

- unificação das eleiçóes nacionais, estaduais e municipais?

- eleição majoritária para Deputados ou voto distrital misto?

- fim das coligaçóes proporcionais?

- cláusula de desempenho para manutenção de partidos políticos?

- redução da maioridade penal?

Certamente que haverá interesse do povo em respondê-las, mas também por isso uma última pergunta que fica no ar: os agentes políticos pagarão para ver a democracia se realizar sem sua tutela?

\section{Referências}

AGRA, Walber de Moura. Temas polêmicos do direito eleitoral. Belo Horizonte: Fórum, 2012.

BOBBIO, Norberto. As ideologias e o poder em crise. 4. ed. Brasília: Universidade de Brasília, 1999.

11 Pauta extraída do portal da Câmara dos Deputados, acessível em: <http://www2.camara.leg.br/atividade-legislativa/comissoes/comissoes-temporarias/especiais/55a-legislatura/pec-182-07-reforma-politica>. Acesso em 03 de abr. 2015. 
O Futuro da Democracia Uma Defesa das Regras do Jogo. 6. ed. Rio de Janeiro: Paz e Terra, 1999.

BRASIL. Constituição (1988). Constituição da República Federativa do Brasil. Brasília: Senado Federal, 1988. Disponível em <http://www.planalto.gov.br/ccivil_03/ Constituicao/Constituicao.htm>. Acesso em: 31 mar. 2015.

BRASIL. Lei 9.504, de 30 de setembro de 1997. Estabelece normas para as eleições. Diário Oficial [da] Uniáo, Brasília, DF, $1^{\circ}$ de outubro de 1997. Disponível em http:// www.planalto.gov.br/ccivil_03/leis/19504.htm. Acesso em: 15 de maio. 2015.

BRASIL. Lei 9.709, de 18 de novembro de 1998. Regulamenta a execução do disposto nos incisos I, II e III do art. 14 da Constituição Federal. Diário Oficial [da] Uniáo, Brasília, DF, 19 de novembro de 1998. Disponível em: <http://www.planalto.gov. br/ccivil_03/leis/19709.htm>. Acesso em: 31 de mar. De 2015.

BRASIL. Lei no 4.737, de 15 de julho de 1965. Institui o Código Eleitoral. Diário Oficial [da] União. Brasília, DF, 19 de julho de 1965, retificado em 30 de julho de 1965. Disponível em: < http://www.planalto.gov.br/ccivil_03/leis/14737.htm >. Acesso em: 31 de mar. 2015.

BRASIL. Supremo Tribunal Federal. Ação Declaratória de Constitucionalidade no 29. Plenário, Relator: Ministro Luiz Fux. Data da publicação 29.06.2012. Disponível em: <http://redir.stf.jus.br/paginadorpub/paginador.jsp?docTP=TP\&docID=2243342>. Acesso em: 31 mar. 2015.

BRASIL. Tribunal Superior Eleitoral. Agravo Regimental na Representação no 1251, originária de Fortaleza/Ceará. Relator: Ministro Francisco Cesar Asfor Rocha. DJ, 18 de dez. de 2006. Diário Oficial da União, Brasília, 18 de dez. de 2006, p. 67. Disponível em <http://inter03.tse.jus.br/InteiroTeor/pesquisa/actionGetBinary. do?tribunal=TSE\&processoNumero $=1251 \&$ processoClasse $=R P \&$ decisaoData $=20061130 \&$ de cisaoNumero $=\&$ protocolo $=232212006 \&$ noCache $=0.931019912706688>$. Acesso em: 27 maio 2015.

BONAVIDES, Paulo. Teoria Constitucional da Democracia Participativa. 3. ed. São Paulo: Malheiros, 2003.

BRÊTAS, Ronaldo de Carvalho Dias. Responsabilidade do Estado pela Função Jurisdicional. Belo Horizonte: Del Rey, 2004.

CÂMARA DOS DEPUTADOS. PEC 182/07 - Reforma Política. Disponível em: <http://www2.camara.leg.br/atividade-legislativa/comissoes/comissoes-temporarias/especiais/55a-legislatura/pec-182-07-reforma-politica>. Acesso em: 03 abr. 2015. 
CANOTILHO, José Joaquim Gomes. Direito Constitucional e Teoria da Constituição. 7. ed. 9. reimp. Coimbra: Almedina, p. 75, 2003.

CANOTILHO, José Joaquim Gomes; MOREIRA, Vital. Constituiçáo da República Portuguesa anotada. 1. ed. São Paulo: Revista dos Tribunais, Coimbra, Portugal: Coimbra, 2007, v. 1.

CASTRO, Edson de Resende. Curso de Direito Eleitoral. 7. ed. Belo Horizonte: Del Rey, 2014.

CHEVALLIER, Jacques. O Estado Pós-Moderno. Belo Horizonte: Fórum, 2009.

COSTA, Adriano Soares da. Instituiçóes de direito eleitoral. Belo Horizonte: Del Rey, 2012.

COSTA, Fabrício Veiga. Mérito Processual. A formação participada nas açóes coletivas. Belo Horizonte: Arraes, 2012.

DALLA-ROSA, Luiz Vergílio. Uma Teoria do Discurso Constitucional. São Paulo: Landy, 2002.

DUARTE, Maria Luisa. Comentário ao art. 44 Direito de Petição. In: SILVEIRA, Alessandra; CANOTILHO, Mariana (Coord.). Carta dos Direitos Fundamentais da Uniáo Europeia Comentada. Coimbra: Almedina, 2013, p. 514-518.

FERRAJOLI, Luigi. Poteri selvaggi. Bari: Laterza, 2011

FIORAVANTI, Maurizio. Los Derechos Fundamentales Apuntes de Historia de Las Constituiciones. Madri: Trotta, 2009.

GOMES, José Jairo. Direito Eleitoral. 7. ed. São Paulo: Atlas, 2011.

GONÇALVES, Aroldo Plínio. Técnica Processual e Teoria do Processo. 1. ed. Rio de Janeiro: Aide, 1992.

GRESTA, Roberta Maia. Introdução aos fundamentos da processualidade democrática. Rio de Janeiro: Lumen Juris, 2014.

GUEDES, Néviton. Natureza jurídica do plebiscito, do referendo e da iniciativa popular. In: CANOTILHO, J. J. Gomes, MENDES, Gilmar Ferreira, SARLET, Ingo Wolfgang, STRECCK, Lenio Luiz. Comentários à Constituição do Brasil. São Paulo: Saraiva/Almedina, p. 657-674, 2013.

HABERLE, Peter. Hermenêutica Constitucional. A Sociedade Aberta dos Intérpretes da Constituição: Contribuição Para a Interpretação Pluralista e Procedimental da Constituição. Porto Alegre: Sergio Fabris, p. 36-37, 2002.

HABERMAS, Jurgen. Verdade e justificaçáo. São Paulo: Loyola, 2004. 
LÔBO, Edilene. A inclusão do cidadáo no processo eleitoral. Belo Horizonte: Del Rey, 2010

MACHADO, Jónatas. Prefácio. In: SOUZA, Sérgio Ricardo de. Abuso da liberdade de imprensa e pseudocensura: no sistema luso-brasileiro. Rio de Janeiro: Lumen Juris, 2013.

MOREIRA, Luiz; MERLE, Jean-Christophe. Direito e legitimidade. São Paulo: Landy, 2003

OLIVEIRA, Adriano; ROMÃO, Maurício Costa; GADELHA, Carlos. Eleiçóes e Pesquisas Eleitorais Desvendando a Caixa-Preta. Curitiba: Juruá, p. 24, 2012.

OLIVEIRA, Marcelo Roseno de. Controle das eleiçóes: virtudes e vícios do modelo constitucional brasileiro. Belo Horizonte: Fórum, p. 94, 2010.

RAMAYANA, Marcos. Direito Eleitoral. 8. ed. Niterói: Impetus, 2008.

REVISTA VEJA. São Paulo: Abril, ed. 2418, ano 48, n. 12, p. 12, 25 de mar. de 2015

RIDOLA, Paolo. Democrazia rappresentativa e parlamentarismo. Torino: G. Giapppichelli, 2011.

ROCHA, Luciano Velasque. Açóes Coletivas. O problema da legitimidade para agir. Rio de Janeiro: Forense, 2007.

ROSANVALLON, Pierre. La legitimidade democrática. 1. ed. Ediciones Madrid: Paidòs Ibérica, 2010.

ROSENFELD, Michael. A identidade do sujeito constitucional. Trad. De Menelick de Carvalho Netto, Belo Horizonte: Mandamentos, 2003.

TRIBUNAL SUPERIOR ELEITORAL. Eleições. Plebiscitos e Referendos. Brasília, 2015. Disponível em: <http://www.tse.jus.br/eleicoes/plebiscitos-e-referendos/plebiscito-e-referendo >. Acesso em: 31 mar. 2015.

VIANA, Rodolfo Pereira. Tutela coletiva no direito eleitoral: controle social e fiscalização das eleiçóes. Rio de Janeiro: Lumen Juris, p. 38, 2008.

VIANNA, Luiz Wenwck et al. A judicialização da política e das relaçóes sociais no Brasil. Rio de Janeiro: Revan, 1999. 